\title{
Appendix 2
}

\section{A Declaration on Europe}

The British-Czechoslovak Declaration on Europe, below, is taken from file FO 371/188501, PRO.

1. Affairs of Europe must be conducted in accordance with the purposes and principles of the UN Charter. There is a broad tradition which is shared by all and it can only be to the advantage of all to build upon shared experiences and to recognise common interests. There is not least a common interest in survival.

2. The prosperity of Europe and the welfare of its citizens requires bilateral and general co-operation in economic, social and cultural matters. It is clear that there is today a greater popular understanding than ever before of the need to overcome the barriers impeding such cooperation, to avoid wasteful competition and to recognise the necessity of solidarity of mankind as a whole. It is the duty of all the Governments concerned to respond to this.

3. Security in Europe, as elsewhere in the world, requires that the relations between states should be conducted in accordance with the principles and purposes of the United Nations Charter. There must be respect for the sovereign equality and territorial integrity of states of peoples. There must be non-intervention in the internal affairs of others. International agreements must be carried out in good faith. There must be recognition of the duty to refrain from the threat or use of force in any manner inconsistent with the purposes of the UN Charter. Any disputes and difficulties which arise must be settled by peaceful means.

4. The stability of Europe requires a Solution of the situation in Central Europe with due regard to the purposes and principles of the United Nations and in accordance with justice and the wishes of the peoples concerned.

5. In the pursuit of prosperity, security, and stability in Europe the efforts of Governments will be greatly supported by an informed public opinion convinced that the aim of policy is the welfare of the peoples in accordance with justice and equity. Public opinion will be the more convinced if 
it is satisfied that in the pursuit of these aims Governments are making progress, even on a limited basis, wherever progress is possible.

6. Therefore in formulating their policies towards each other, the Governments concerned should be guided by the following principles and objectives which are both interconnected and mutually reinforcing, and which are necessary to the peace and prosperity of Europe and to ensuring its proper role in the world community of nations:

(i) Agreements on a limited basis should be sought in fields of activity where the common interest is clear, in order to prepare the way for more far-reaching accords;

(ii) To help raise the living standards throughout Europe and to permit the more efficient use of resources, all the states concerned should seek to improve and extend their economic relationships - should keep constantly in review their trading and economic policies so that these may produce the greatest mutual advantage, they should seek actively to develop international standards and agreed systems of measurement and calibration. It should be their special concern to identify and overcome those obstacles to closer economic co-operation which arise from differences in their various economic systems;

(iii) In the interest of mutual understanding which depends upon the exchange of experiences and ideas, wider contacts should be encouraged by Governments at all levels;

(iv) In Europe, as elsewhere, all economically-advanced states whatever their political structure, should recognise a common responsibility to co-operate in helping, to the best of their ability, to solve the economic, social, and technological problems which face the developing countries of the world;

(v) The resort to force must be renounced as a means of settling any existing disputes or any disputes which may arise in the future;

(vi) There must be a vigorous search for progress on measures of arms control and disarmament, with general and complete disarmament under effective international control as the final objective.

7. Every Government subscribing to this Declaration declares its intention to be guided by these principles and objectives and affirms its intention to work for the prosperity, security, and stability of Europe. To this end it also declares its willingness to develop scientific, technical, and cultural co-operation, believing that in this fashion it is possible to help realise individually and in partnership each country's human and material potential. It will also seek to promote the best possible commercial and economic relations with the other states subscribing to the Declaration, and in particular to consider arrangements for economic consultation and the exchange of views and information in this and other fields in whatever form seems most convenient in each particular case. 